\title{
Tumor-derived alpha-fetoprotein impairs the differentiation and $T$ cell stimulatory activity of human dendritic cells
}

\author{
Angela D Pardee ${ }^{1 *}$, Jian Shi ${ }^{1}$, Lisa H Butterfield ${ }^{2}$ \\ From Society for Immunotherapy of Cancer 29th Annual Meeting \\ National Harbor, MD, USA. 6-9 November 2014
}

Several tumor-derived factors have been implicated in DC dysfunction in cancer patients. Alpha-fetoprotein (AFP) is an oncofetal antigen that is highly expressed in abnormalities of prenatal development and several epithelial cancers, including hepatocellular carcinoma (HCC). In HCC patients exhibiting high levels of serum AFP, we have observed a lower ratio of myeloid-toplasmacytoid circulating DC compared to patients with low serum AFP levels and healthy donors, suggesting that AFP alters DC differentiation in vivo. To test the effect of AFP on DC differentiation in vitro, peripheral blood monocytes from healthy donors were cultured in the presence of cord blood-derived normal AFP (nAFP) or HCC tumor-derived AFP (tAFP), and DC phenotype and function was assessed. Although the nAFP and tAFP isoforms only differ at one carbohydrate group, low (physiological) levels of tAFP, but not nAFP, significantly inhibited DC differentiation. tAFP-conditioned DC expressed diminished levels of DC maturation markers, retained a monocyte-like morphology, exhibited limited production of inflammatory mediators, and failed to induce robust $\mathrm{T}$ cell proliferative responses. Mechanistic studies revealed that the suppressive activity of tAFP is dependent on the presence of low molecular weight (LMW) species that $i$ ) co-purify with tAFP, and $i$ ) are abundant in the LMW fractions of both tumor and non-tumor cell lysates. These data reveal the unique ability of tAFP to serve as a chaperone protein for ubiquitous LMW molecules, which function cooperatively to impair DC differentiation and function. Therefore, novel therapeutic approaches that antagonize the regulatory properties of tAFP will be critical to enhance immunity and improve clinical outcomes.

1Department of Medicine, University of Pittsburgh, Pittsburgh, PA, USA Full list of author information is available at the end of the article

\section{Authors' details}

'Department of Medicine, University of Pittsburgh, Pittsburgh, PA, USA. 2Departments of Medicine, Immunology and Surgery and University of Pittsburgh Cancer Institute, Pittsburgh, PA, USA.

Published: 6 November 2014

doi:10.1186/2051-1426-2-S3-P229

Cite this article as: Pardee et al.: Tumor-derived alpha-fetoprotein impairs the differentiation and T cell stimulatory activity of human dendritic cells. Journal for ImmunoTherapy of Cancer 2014 2(Suppl 3):P229.
Submit your next manuscript to BioMed Central and take full advantage of:

- Convenient online submission

- Thorough peer review

- No space constraints or color figure charges

- Immediate publication on acceptance

- Inclusion in PubMed, CAS, Scopus and Google Scholar

- Research which is freely available for redistribution
() Biomed Central 